\section{A Case Study of a Currency Crisis: The Russian Default of 1998}

\author{
Abbigail J. Chiodo and Michael T. Owyang
}

A currency crisis can be defined as a speculative attack on a country's currency that can result in a forced devaluation and possible debt default. One example of a currency crisis occurred in Russia in 1998 and led to the devaluation of the ruble and the default on public and private debt. ${ }^{1}$ Currency crises such as Russia's are often thought to emerge from a variety of economic conditions, such as large deficits and low foreign reserves. They sometimes appear to be triggered by similar crises nearby, although the spillover from these contagious crises does not infect all neighboring economies - only those vulnerable to a crisis themselves.

In this paper, we examine the conditions under which an economy can become vulnerable to a currency crisis. We review three models of currency crises, paying particular attention to the events leading up to a speculative attack, including expectations of possible fiscal and monetary responses to impending crises. Specifically, we discuss the symptoms exhibited by Russia prior to the devaluation of the ruble. In addition, we review the measures that were undertaken to avoid the crisis and explain why those steps may have, in fact, hastened the devaluation.

The following section reviews the three generations of currency crisis models and summarizes the conditions under which a country becomes vulnerable to speculative attack. The third section examines the events preceding the Russian default of 1998 in the context of a currency crisis. The fourth section applies the aforementioned models to the Russian crisis.

\section{CURRENCY CRISES: WHAT DOES MACROECONOMIC THEORY SUGGEST?}

A currency crisis is defined as a speculative attack on country A's currency, brought about by

\footnotetext{
Abbigail J. Chiodo is a senior research associate and Michael T. Owyang is an economist at the Federal Reserve Bank of St. Louis. The authors thank Steven Holland, Eric Blankmeyer, John Lewis, and Rebecca Beard for comments and suggestions and Victor Gabor at the World Bank for providing real GDP data.

(C) 2002, The Federal Reserve Bank of St. Louis.
}

agents attempting to alter their portfolio by buying another currency with the currency of country A. ${ }^{2}$ This might occur because investors fear that the government will finance its high prospective deficit through seigniorage (printing money) or attempt to reduce its nonindexed debt (debt indexed to neither another currency nor inflation) through devaluation. A devaluation occurs when there is market pressure to increase the exchange rate (as measured by domestic currency over foreign currency) because the country either cannot or will not bear the cost of supporting its currency. In order to maintain a lower exchange rate peg, the central bank must buy up its currency with foreign reserves. If the central bank's foreign reserves are depleted, the government must allow the exchange rate to float up - a devaluation of the currency. This causes domestic goods and services to become cheaper relative to foreign goods and services. The devaluation associated with a successful speculative attack can cause a decrease in output, possible inflation, and a disruption in both domestic and foreign financial markets. ${ }^{3}$

The standard macroeconomic framework applied by Fleming (1962) and Mundell (1963) to international issues is unable to explain currency crises. In this framework with perfect capital mobility, a fixed exchange rate regime results in capital flight when the central bank lowers interest rates and results in capital inflows when the central bank raises interest rates. Consequently, the efforts of the monetary authority to change the interest rate are undone by the private sector. In a flexible exchange rate regime, the central bank does not intervene in the foreign exchange market and all balance of payment surpluses or deficits must be financed by private capital outflows or inflows, respectively.

The need to explain the symptoms and remedies of a currency crisis has spawned a number of models designed to incorporate fiscal deficits, expectations, and financial markets into models with purchasing power parity. These models can be grouped into three generations, each of which is intended to explain specific aspects that lead to a currency crisis.

\footnotetext{
1 Kharas, Pinto, and Ulatov (2001) provide a history from a fundamentalsbased perspective, focusing on taxes and public debt issues. We endeavor to incorporate a role for monetary policy.

2 The speculative attack need not be successful to be dubbed a currency crisis.

3 Burnside, Eichenbaum, and Rebelo (2001) show that the government has at its disposal a number of mechanisms to finance the fiscal costs of the devaluation. Which policy is chosen determines the inflationary effect of the currency crisis.
} 


\section{First-Generation Models}

The first-generation models of a currency crisis developed by Krugman (1979) and Flood and Garber (1984) rely on government debt and the perceived inability of the government to control the budget as the key causes of the currency crisis. These models argue that a speculative attack on the domestic currency can result from an increasing current account deficit (indicating an increase in the trade deficit) or an expected monetization of the fiscal deficit. The speculative attack can result in a sudden devaluation when the central bank's store of foreign reserves is depleted and it can no longer defend the domestic currency. Agents believe that the government's need to finance the debt becomes its overriding concern and eventually leads to a collapse of the fixed exchange rate regime and to speculative attacks on the domestic currency.

Krugman presents a model in which a fixed exchange rate regime is the inevitable target of a speculative attack. An important assumption in the model is that a speculative attack is inevitable. The government defends the exchange rate peg with its store of foreign currency. As agents change the composition of their portfolios from domestic to foreign currency (because rising fiscal deficits increase the likelihood of devaluation, for example), the central bank must continue to deplete its reserves to stave off speculative attacks. The crisis is triggered when agents expect the government to abandon the peg. Anticipating the devaluation, agents convert their portfolios from domestic to foreign currency by buying foreign currency from the central bank's reserves. The central bank's reserves fall until they reach the critical point when a peg is no longer sustainable and the exchange rate regime collapses. The key contribution of the first-generation model is its identification of the tension between domestic fiscal policy and the fixed exchange rate regime. ${ }^{4}$

While the first-generation models help explain some of the fundamentals that cause currency crises, they are lacking in two key aspects. First, the standard first-generation model requires agents to suddenly increase their estimates of the likelihood of a devaluation (perhaps through an increase in expected inflation). Second, they do not explain why the currency crises spread to other countries.

\section{Second-Generation Models}

The second-generation models suggested by Obstfeld (1994), Eichengreen, Rose, and Wyplosz
(1997), and others are particularly useful in explaining self-fulfilling contagious currency crises. One possible scenario suggested by these models involves a devaluation in one country affecting the price level (and therefore the demand for money) or the current account by a reduction of exports in a neighboring country. In either case, devaluation in a neighboring country becomes increasingly likely.

Eichengreen, Rose, and Wyplosz (1997) find that a correlation exists between the likelihood of default across countries. That is, the probability of a speculative attack in country A increases when its trading partner, country B, experiences an attack of its own. They estimate that a speculative attack somewhere in the world increases the probability of a domestic currency crisis by about 8 percent. The spillover from one currency crisis into neighboring countries can be attributed to a number of different scenarios. First, an economic event, such as a war or an oil price shock, that is common to a geographical area or a group of trading partners can affect those economies simultaneously; in addition, an individual shock can be transmitted from one country to another via trade. Second, a devaluation or default in one country can raise expectations of the likelihood of a devaluation in other countries. Expectations can rise either because countries are neighboring trade partners or because they have similar macroeconomic policies or conditions (e.g., high unemployment or high government debt). Since the crises are self-fulfilling, these expectations make the likelihood of devaluation increase as well. Lastly, a devaluation can be transmitted via world financial markets to other susceptible countries. Any combination of scenarios can serve as an explanation of the apparent international linkages that are responsible for the spread of speculative attacks from one country to another.

\section{Third-Generation Models}

The literature on contagious currency crises has helped clarify the spread of devaluations and their magnitudes. However, the first two generations of models have not provided a policy recommendation for the central bank in the face of a crisis. Indeed, Krugman's first-generation model suggests that a crisis cannot be thwarted - that once a devaluation is expected, it is inevitable. Thus, third-generation

\footnotetext{
4 Obstfeld (1986) outlines a multiple equilibrium model in which a currency crisis is brought about when government policy (financing a deficit through seignorage, for example) causes agents to expect a crisis and push the economy to a bad equilibrium.
} 
currency crisis models suggested by Krugman (1999) and Aghion, Bacchetta, and Banarjee $(2000,2001)$ examine the effects of monetary policy in a currency crisis.

These models argue that fragility in the banking and financial sector reduces the amount of credit available to firms and increases the likelihood of a crisis. They suggest that a currency crisis is brought on by a combination of high debt, low foreign reserves, falling government revenue, increasing expectations of devaluation, and domestic borrowing constraints. Firms' access to domestic loans is constrained by assuming they can borrow only a portion of their wealth (somewhat similar to requiring the firm to collateralize all domestic loans). In these lending-constrained economies, the credit market does not clear: interest rates rise, but not enough to compensate investors for the increase in perceived default risk. Increasing the domestic interest rate, then, does not raise the supply of domestic lending in the normal fashion. Moral hazard, a firm's ability to take its output and default on its loan, forces banks to restrict lending. Therefore, increasing the interest rate reduces the amount of loans as it increases firms' incentive to default.

These third-generation models offer a role for monetary policy (aside from the decision to abandon the exchange rate peg) through a binding credit constraint in an imperfect financial market. If firms' leverage in the domestic market is substantially reduced, they may be forced to accumulate a large amount of foreign-denominated debt. When, in domestic markets, the amount of available lending depends on the nominal interest rate, the central bank can deepen a crisis by further reducing firms' ability to invest. The typical prescription for a currency crisis is to raise interest rates and raise the demand for domestic currency. ${ }^{5}$ However, in the third-generation models, an interest rate increase can greatly affect the amount of lending and further restrict firms' access to financial capital. In cases where lending is highly sensitive to the interest rate, an increase in the nominal interest rate can be detrimental, altering the productive capacity of the economy by stifling investment. The perceived drop in output puts additional pressure on the exchange rate, perhaps through actual or expected tax revenue, exacerbating the crisis. In this situation, an alternative strategy for the central bank is warranted: it is actually beneficial to lower the interest rate to spur investment. 6

These three generations of models suggest four factors that can influence the onset and magnitude of a currency crisis. Domestic public and private debt, expectations, and the state of financial markets can, in combination with a pegged exchange rate, determine whether a country is susceptible to a currency crisis and also determine the magnitude and success of a speculative attack. In the next section, we provide an example of a recent currency crisis, keeping these four factors in mind.

\section{THE RUSSIAN DEFAULT: A BRIEF HISTORY}

After six years of economic reform in Russia, privatization and macroeconomic stabilization had experienced some limited success. Yet in August 1998, after recording its first year of positive economic growth since the fall of the Soviet Union, Russia was forced to default on its sovereign debt, devalue the ruble, and declare a suspension of payments by commercial banks to foreign creditors. What caused the Russian economy to face a financial crisis after so much had been accomplished? This section examines the sequence of events that took place in Russia from 1996 to 1998 and the aftermath of the crisis. (For a timeline, see Table 1.)

\section{6 and 1997}

Optimism and Reform. In April 1996, Russian officials began negotiations to reschedule the payment of foreign debt inherited from the former Soviet Union. The negotiations to repay its sovereign debt were a major step toward restoring investor confidence. On the surface, 1997 seemed poised to be a turning point toward economic stability.

- The trade surplus was moving toward a balance between exports and imports (see Figure 1).

- Relations with the West were promising: the World Bank was prepared to provide expanded assistance of $\$ 2$ to $\$ 3$ billion per year and the International Monetary Fund (IMF) continued to meet with Russian officials and provide aid.

- Inflation had fallen from 131 percent in 1995 to 22 percent in 1996 and 11 percent in 1997 (see Figure 2).

- Output was recovering slightly.

5 Flood and Jeanne (2000) argue that increasing domestic currency interest rates can act only to speed devaluation.

6 The expansionary monetary policy in this case is assumed not to be inflationary since it only alleviates liquidity constraints. 


\section{Table 1}

\section{A Timeline of Russian Events}

April 1996

1997

September/October 1997

November 11, 1997

December 1997

February 1998

March 23, 1998

April 1998

April 24, 1998

Early May 1998

May 19, 1998

Mid May 1998

May 23, 1998

May 27, 1998

Summer 1998

July 20, 1998

August 13, 1998

August 17, 1998

August 23-24, 1998

September 2, 1998

December 1998
Negotiations with the Paris and London Clubs for repayment of Soviet debt begin.

Trade surplus moving toward balance.

Inflation around 11 percent.

Oil selling at $\$ 23 /$ barrel.

Analysts predict better credit ratings for Russia.

Russian banks increase foreign liabilities.

Real wages sagging.

Only 40 percent of workforce being paid fully and on time.

Public-sector deficit high.

Negotiations with Paris and London Clubs completed.

Asian crisis causes a speculative attack on the ruble.

CBR defends the ruble, losing $\$ 6$ billion.

Year ends with 0.8 percent growth.

Prices of oil and nonferrous metal begin to drop.

New tax code submitted to the Duma.

IMF funds requested.

Yelstin fires entire government and appoints Kiriyenko.

Continued requests for IMF funds.

Another speculative attack on the ruble.

Duma finally confirms Kiriyenko's appointment.

Dubinin warns government ministers of impending debt crisis, with reporters in the audience.

Kiriyenko calls the Russian government "quite poor."

CBR increases lending rate from 30 percent to 50 percent and defends the ruble with $\$ 1$ billion.

Lawrence Summers not granted audience with Kiriyenko.

Oil prices continue to decrease.

Oil and gas oligarchs advocate devaluation of ruble to increase value of their exports.

IMF leaves Russia without agreement on austerity plan.

CBR increases the lending rate again to 150 percent.

Russian government formulates and advertises anti-crisis plan.

IMF approves an emergency aid package (first disbursement to be $\$ 4.8$ billion).

Russian stock, bond, and currency markets weaken as a result of investor fears of devaluation; prices diminish.

Russian government devalues the ruble, defaults on domestic debt, and declares a moratorium on payment to foreign creditors.

Kiriyenko is fired.

The ruble is floated.

Year ends with a decrease in real output of 4.9 percent.

NOTE: CBR, Central Bank of Russia. 


\section{Figure 1}

Russian Merchandise Trade Balance

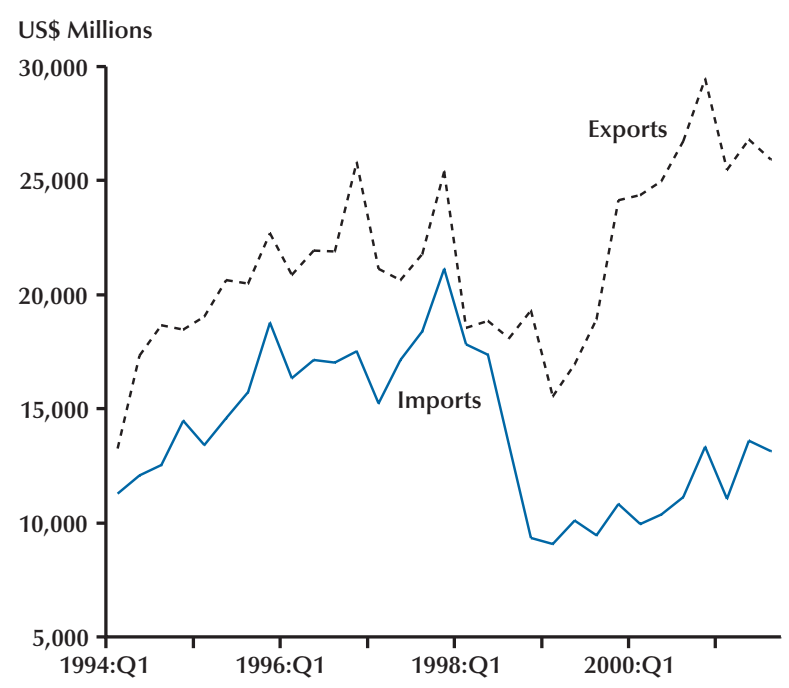

SOURCE: CBR.

- A narrow exchange rate band was in place keeping the exchange rate between 5 and 6 rubles to the dollar (see Figure 3).

- And oil, one of Russia's largest exports, was selling at \$23 per barrel-a high price by recent standards. (Fuels made up more than 45 percent of Russia's main export commodities in 1997.)

In September 1997, Russia was allowed to join the Paris Club of creditor nations after rescheduling the payment of over $\$ 60$ billion in old Soviet debt to other governments. Another agreement for a 23-year debt repayment of $\$ 33$ billion was signed a month later with the London Club. Analysts predicted that Russia's credit ratings would improve, allowing the country to borrow less expensively. Limitations on the purchase of government securities by nonresident investors were removed, promoting foreign investment in Russia. By late 1997, roughly 30 percent of the GKO (a short-term government bill) market was accounted for by nonresidents. The economic outlook appeared optimistic as Russia ended 1997 with reported economic growth of 0.8 percent.

Revenue, Investment, and Debt. Despite the prospects for optimism, problems remained. On average, real wages were less than half of what they were in 1991, and only about 40 percent of the work force was being paid in full and on time. Per capita direct foreign investment was low, and regu-

\section{Figure 2}

\section{CPI Inflation}

Percent Change over Previous Year

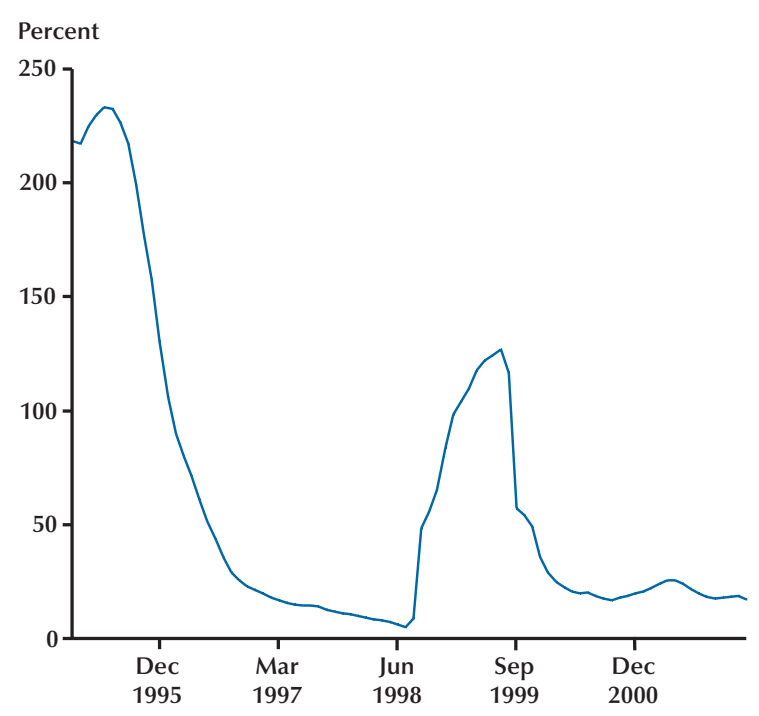

SOURCE: IMF.

\section{Figure 3}

\section{Exchange Rate}

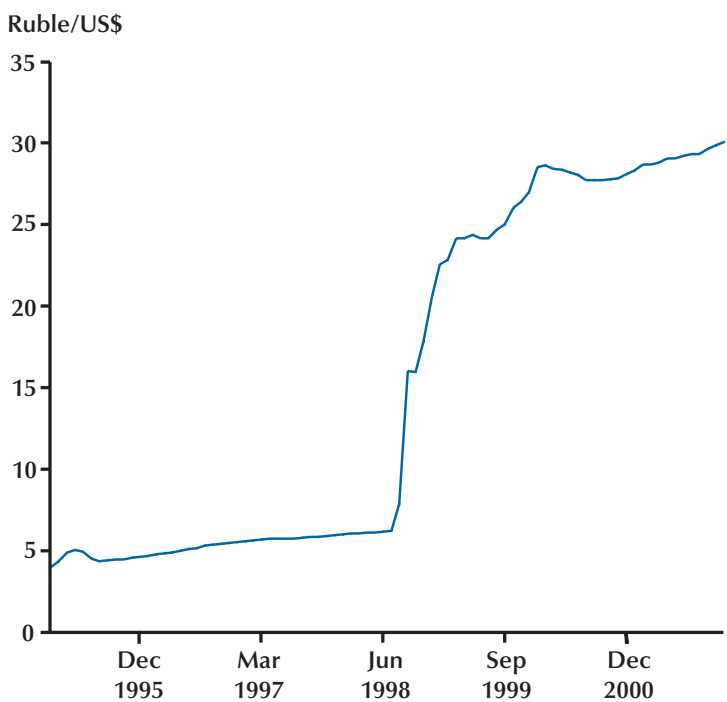

SOURCE: IMF (end of period data).

lation of the natural monopolies was still difficult due to unrest in the Duma, Russia's lower house of Parliament. Another weakness in the Russian economy was low tax collection, which caused the 
public sector deficit to remain high. The majority of tax revenues came from taxes that were shared between the regional and federal governments, which fostered competition among the different levels of government over the distribution. According to Shleifer and Treisman (2000), this kind of tax sharing can result in conflicting incentives for regional governments and lead them to help firms conceal part of their taxable profit from the federal government in order to reduce the firms' total tax payments. In return, the firm would then make transfers to the accommodating regional government. This, Shleifer and Treisman suggest, may explain why federal revenues dropped more rapidly than regional revenues.

Also, the Paris Club's recognition of Russia as a creditor nation was based upon questionable qualifications. One-fourth of the assets considered to belong to Russia were in the form of debt owed to the former Soviet Union by countries such as Cuba, Mongolia, and Vietnam. Recognition by the Paris Club was also based on the old, completely arbitrary official Soviet exchange rate of approximately 0.6 rubles to the dollar (the market exchange rate at the time was between 5 and 6 rubles to the dollar). The improved credit ratings Russia received from its Paris Club recognition were not based on an improved balance sheet. Despite this, restrictions were eased and lifted and Russian banks began borrowing more from foreign markets, increasing their foreign liabilities from 7 percent of their assets in 1994 to 17 percent in 1997.

Meanwhile, Russia anticipated growing debt payments in the coming years when early credits from the IMF would come due. Policymakers faced decisions to decrease domestic borrowing and increase tax collection because interest payments were such a large percentage of the federal budget. In October 1997, the Russian government was counting on 2 percent economic growth in 1998 to compensate for the debt growth. Unfortunately, events began to unfold that would further strain Russia's economy; instead of growth in 1998, real GDP declined 4.9 percent.

The Asian Crisis. A few months earlier, in the summer of 1997, countries in the Pacific Rim experienced currency crises similar to the one that eventually affected Russia. In November 1997, after the onset of this East Asian crisis, the ruble came under speculative attack. The Central Bank of Russia (CBR) defended the currency, losing nearly $\$ 6$ billion (U.S. dollars) in foreign-exchange reserves. At the same time, non-resident holders of short-term government bills (GKOs) signed forward contracts with the CBR to exchange rubles for foreign currency, which enabled them to hedge exchange rate risk in the interim period. ${ }^{7}$ According to Desai (2000), they did this in anticipation of the ruble losing value, as Asian currencies had. Also, a substantial amount of the liabilities of large Russian commercial banks were off-balance-sheet, consisting mostly of forward contracts signed with foreign investors. Net obligations of Russian banks for such contracts were estimated to be at least $\$ 6$ billion by the first half of 1998. Then another blow was dealt to the Russian economy: in December 1997, the prices of oil and nonferrous metal, up to two-thirds of Russia's hard-currency earnings, began to drop.

\section{8}

Government, Risk, and Expectations. With so many uncertainties in the Russian economy, investors turned their attention toward Russian default risk. To promote a stable investment environment, in February 1998, the Russian government submitted a new tax code to the Duma, with fewer and more efficient taxes. The new tax code was approved in 1998, yet some crucial parts that were intended to increase federal revenue were ignored. Russian officials sought IMF funds but agreements could not be reached. By late March the political and economic situation had become more dire, and, on March 23, President Yeltsin abruptly fired his entire government, including Prime Minister Viktor Chernomyrdin. In a move that would challenge investor confidence even further, Yeltsin appointed 35-year-old Sergei Kiriyenko, a former banking and oil company executive who had been in government less than a year, to take his place.

While fears of higher interest rates in the United States and Germany made many investors cautious, tensions rose in the Russian government. The executive branch, the Duma, and the CBR were in conflict. Prompted by threats from Yeltsin to dissolve Parliament, the Duma confirmed Kiriyenko's appointment on April 24 after a month of stalling. In early May, during a routine update, CBR chair Sergei Dubinin warned government ministers of a debt crisis within the next three years. Unfortunately, reporters were in the audience. Since the Asian crisis had heightened investors' sensitivity to currency stability, Dubinin's

\footnotetext{
7 The requirement of forward contracts was the CBR's way of preventing runs on its foreign currency reserves.
} 
restatement of bank policy was misinterpreted to mean that the Bank was considering a devaluation of the ruble. In another public relations misunderstanding, Kiriyenko stated in an interview that tax revenue was 26 percent below target and claimed that the government was "quite poor now." In actuality, the government was planning to cut government spending and accelerate revenue, but these plans were never communicated clearly to the public. Instead, people began to expect a devaluation of the ruble.

Investors' perceptions of Russia's economic stability continued to decline when Lawrence Summers, one of America's top international-finance officials, was denied a meeting with Kiriyenko while in Russia. An inexperienced aide determined that Summers's title, Deputy Secretary of the Treasury, was unworthy of Kiriyenko's audience and the two never met. At the same time, the IMF left Russia, unable to reach an agreement with policymakers on a 1998 austerity plan. Word spread of these incidents, and big investors began to sell their government bond portfolios and Russian securities, concerned that relations between the United States and Russia were strained.

Liquidity, Monetary Policy, and Fiscal Policy. By May 18, government bond yields had swelled to 47 percent. With inflation at about 10 percent, Russian banks would normally have taken the government paper at such high rates. Lack of confidence in the government's ability to repay the bonds and restricted liquidity, however, did not permit this. As depositors and investors became increasingly cautious of risk, these commercial banks and firms had less cash to keep them afloat. The federal government's initiative to collect more taxes in cash lowered banks' and firms' liquidity. ${ }^{8}$ Also, in 1997, Russia had created a U.S.-style treasury system with branches, which saved money and decreased corruption, yet also decreased the amount of cash that moved through banks. The banks had previously used these funds to buy bonds. Also, household ruble deposits increased by only 1.3 billion in 1998, compared with an increase of 29.8 billion in 1997.

The CBR responded by increasing the lending rate to banks from 30 to 50 percent, and in two days used $\$ 1$ billion of Russia's low reserves to defend the ruble. (Figure 4 shows the lending rate.) However, by May 27, demand for bonds had plummeted so much that yields were more than 50 percent and the government failed to sell enough bonds at its

\section{Figure 4}

\section{Lending Rate}

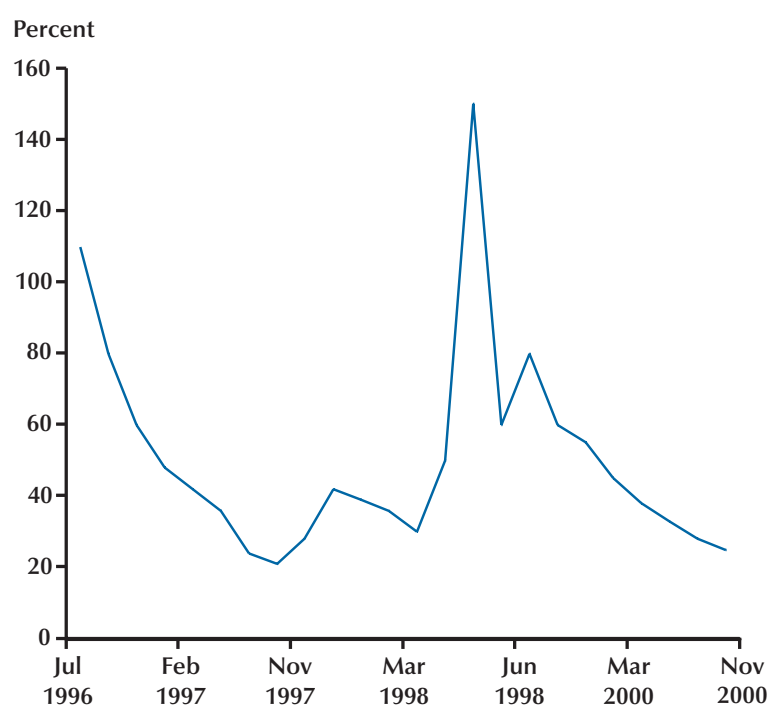

SOURCE: CBR.

weekly auction to refinance the debt coming due.

Meanwhile, oil prices had dropped to $\$ 11$ per barrel, less than half their level a year earlier. Oil and gas oligarchs were advocating a devaluation of the ruble, which would increase the ruble value of their exports. In light of this, the CBR increased the lending rate again, this time to 150 percent. CBR chairman Sergei Dubinin responded by stating "When you hear talk of devaluation, spit in the eye of whoever is talking about it" (quoted in Shleifer and Treisman, 2000, p. 149).

The government formed and advertised an anticrisis plan, requested assistance from the West, and began bankruptcy processes against three companies with large debts from back taxes. Kiriyenko met with foreign investors to reassure them. Yeltsin made nightly appearances on Russian television, calling the nation's financial elite to a meeting at the Kremlin where he urged them to invest in Russia. In June the CBR defended the ruble, losing $\$ 5$ billion in reserves.

Despite all of the government efforts being made, there was widespread knowledge of $\$ 2.5$ to $\$ 3$ billion

8 As a result of a 1998 elimination of tax-offsets paper issued by government agencies to pay for goods and services, the receipts of which could be used to decrease their tax duties, banks and companies were forced to provide more cash to pay their taxes, thus lowering their liquidity. 


\section{Figure 5}

\section{The Russian Stock Market}

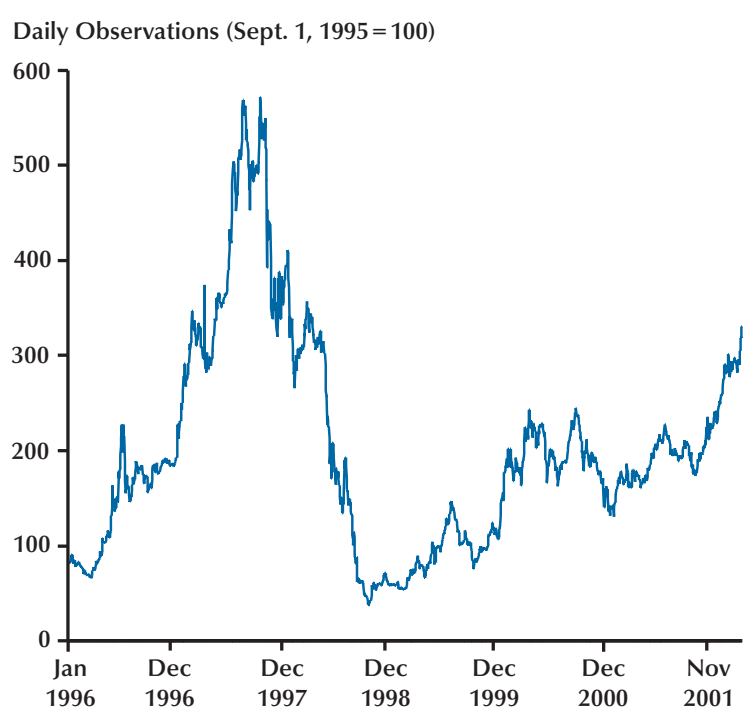

SOURCE: <http://red-stars.com/financial>.

in loans from foreign investors to Russian corporations and banks that were to come due by the end of September. In addition, billions of dollars in ruble futures were to mature in the fall. In July the IMF approved additional assistance of $\$ 11.2$ billion, of which $\$ 4.8$ billion was to be disbursed immediately. Yet between May and August, approximately \$4 billion had left Russia in capital flight, and in 1998 Russia lost around \$4 billion in revenue due to sagging oil prices. After losing so much liquidity, the IMF assistance did not provide much relief.

The Duma, in an effort to protect natural monopolies from stricter regulations, eliminated crucial parts of the IMF-endorsed anti-crisis program before adjourning for vacation. The government had hoped that the anti-crisis plan would bring in an additional 71 billion rubles in revenue. The parts that the Duma actually passed would have increased it by only 3 billion rubles. In vain, lawmakers requested that the Duma reconvene, lowering investors' confidence even further.

Default and Devaluation. On August 13, 1998, the Russian stock, bond, and currency markets collapsed as a result of investor fears that the government would devalue the ruble, default on domestic debt, or both. Annual yields on rubledenominated bonds were more than 200 percent. The stock market had to be closed for 35 minutes as prices plummeted. When the market closed, it was down 65 percent with a small number of shares actually traded. From January to August the stock market had lost more than 75 percent of its value, 39 percent in the month of May alone. (Figure 5 shows the Russian stock market's boom and bust.) Russian officials were left with little choice. On August 17 the government floated the exchange rate, devalued the ruble, defaulted on its domestic debt, halted payment on ruble-denominated debt (primarily GKOs), and declared a 90-day moratorium on payment by commercial banks to foreign creditors.

\section{The Aftermath}

Russia ended 1998 with a decrease in real output of 4.9 percent for the year instead of the small growth that was expected. The collapse of the ruble created an increase in Russia's exports while imports remained low (see Figure 1). Since then, direct investments into Russia have been inconsistent at best. Summarized best by Shleifer and Treisman (2000), "the crisis of August 1998 did not only undermine Russia's currency and force the last reformers from office... it also seemed to erase any remaining Western hope that Russia could successfully reform its economy."

Some optimism, however, still persists. Figure 6 shows Russian real GDP growth, which grew 8.3 percent in 2000 and roughly 5 percent in 2001 lower but still positive. Imports trended up in the first half of 2001, helping to create a trade balance. At the same time, consumer prices grew 20.9 percent and 21.6 percent in 2000 and 2001, respectively, compared with a 92.6 percent increase in 1999. Most of the recovery so far can be attributed to the import substitution effect after the devaluation; the increase in world prices for Russia's oil, gas, and commodity exports; monetary policies; and fiscal policies that have led to the first federal budget surplus (in 2000) since the formation of the Russian Federation.

\section{HOW DO THE THEORIES EXPLAIN THE RUSSIAN CRISIS?}

As discussed earlier, four major factors influence the onset and success of a speculative attack. These key ingredients are (i) an exchange rate peg and a central bank willing or obligated to defend it with a reserve of foreign currency, (ii) rising fiscal deficits that the government cannot control and therefore is likely to monetize (print money to cover the deficit), (iii) central bank control of the interest rate in a 
fragile credit market, and (iv) expectations of devaluation and/or rising inflation. In this section we discuss these aspects in the context of the Russian devaluation. We argue that an understanding of all three generations of models is necessary to evaluate the Russian devaluation. Krugman's (1979) firstgeneration model explains the factors that made Russia susceptible to a crisis. The second-generation models show how contagion and other factors can change expectations to trigger the crisis. The thirdgeneration models show how the central bank can act to prevent or mitigate the crisis.

\section{The Exchange Rate and the Peg}

When the ruble came under attack in November 1997 and June 1998, policymakers defended the ruble instead of letting it float. The real exchange rate did not vary much during 1997 . Clearly a primary component of a currency crisis in the models described here is the central bank's willingness to defend an exchange rate peg. Prior to August 1998, the Russian ruble was subject to two speculative attacks. The CBR made efforts both times to defend the ruble. The defense was successful in November 1997 but fell short in the summer of 1998. Defending the ruble depleted Russia's foreign reserves. Once depleted, the Russian government had no choice but to devalue on August 17, 1998.

\section{Revenue, Deficits, and Fiscal Policy}

Russia's high government debt and falling revenue contributed significantly to its susceptibility to a speculative attack. Russia's federal tax revenues were low because of both low output and the opportunistic practice of local governments helping firms conceal profits. The decrease in the price of oil also lowered output, further reducing Russia's ability to generate tax revenue. Consequently, Russia's revenue was lower than expected, making the ruble ripe for a speculative attack. In addition, a large amount of short-term foreign debt was coming due in 1998, making Russia's deficit problem even more serious. Krugman's first-generation model suggests that a government finances its deficit by printing money (seigniorage) or depleting its reserves of foreign currency. Under the exchange rate peg, however, Russia was unable to finance through seigniorage. Russia's deficit, low revenue, and mounting interest payments put pressure on the exchange rate. Printing rubles would only have increased this pressure because the private sector would still have been able

\section{Figure 6}

\section{Real GDP Growth}

Quarterly Change from Previous Year

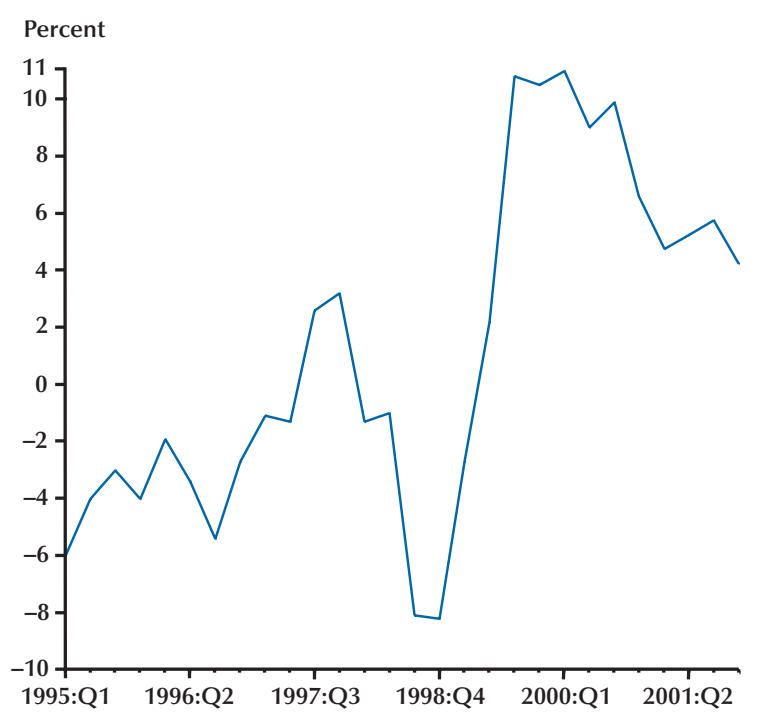

SOURCE: Russian Statistics Committee and International Bank for Reconstruction and Development staff estimates.

to trade rubles for foreign currency at the fixed rate. Thus, whether directly through intervention in the foreign currency market or indirectly by printing rubles, Russia's only alternative under the fixed exchange rate regime was to deplete its stock of foreign reserves.

\section{Monetary Policy, Financial Markets, and Interest Rates}

During the summer of 1998, the Russian economy was primed for the onset of a currency crisis. In an attempt to avert the crisis, the CBR intervened by decreasing the growth of the money supply and twice increasing the lending rate to banks, raising it from 30 to 150 percent. Both rate hikes occurred in May 1998, the same month in which the Russian stock market lost 39 percent of its value. The rise in interest rates had two effects. First, it exacerbated Russia's revenue problems. Its debt grew rapidly as interest payments mounted. This put pressure on the exchange rate because investors feared that Russia would devalue to finance its non-denominated debt. Second, high government debt prevented firms from obtaining loans for new capital and increasing the interest rate did not increase the supply of lending capital available to firms. At the same time, for- 
eign reserves held by the CBR were so low that the government could no longer defend the currency by buying rubles.

\section{Expectations}

Three components fueled the expectations of Russia's impending devaluation and default. First, the Asian crisis made investors more conscious of the possibility of a Russian default. Second, public relations errors, such as the publicized statement to government ministers by the CBR and Kiriyenko's refusal to grant Lawrence Summers an audience, perpetuated agents' perceptions of a political crisis within the Russian government. Third, the revenue shortfall signaled the possible reduction of the public debt burden via an increase in the money supply. This monetization of the debt can be associated with a depreciation either indirectly through an increase in expected inflation or directly in order to reduce the burden of ruble-denominated debt. Each of these three components acted to push the Russian economy from a stable equilibrium to one vulnerable to speculative attack.

\section{CONCLUSION}

In this paper we investigate the events that lead up to a currency crisis and debt default and the policies intended to avert it. Three types of models exist to explain currency crises. Each model explains some factor that has been hypothesized to cause a crisis. After reviewing the three generations of currency crisis models, we conclude that four key ingredients can trigger a crisis: a fixed exchange rate, fiscal deficits and debt, the conduct of monetary policy, and expectations of impending default. Using the example of the Russian default of 1998, we show that the prescription of contractionary monetary policy in the face of a currency crisis can, under certain conditions, accelerate devaluation. While we believe that deficits and the Asian financial crisis contributed to Russia's default, the first-generation model proposed by Krugman (1979) and Flood and Garber (1984) and the second-generation models proposed by Obstfeld (1984) and Eichengreen, Rose, and Wyplosz (1997) do not capture every aspect of the crisis. Specifically, these models do not address the conduct of monetary policy. It is therefore necessary to incorporate both the first-generation model's phenomenon of increasing fiscal deficits and the third-generation model's financial sector fragility. We conclude that the modern currency crisis is a symptom of an ailing domestic economy. In that light, it is inappropriate to attribute a single prescription as the prophylactic or cure for a currency crisis.

\section{REFERENCES}

Aghion, Philippe; Bacchetta, Philippe and Banerjee, Abhijit. "A Simple Model of Monetary Policy and Currency Crises." European Economic Review, May 2000, 44(4-6), pp. 728-38. and "Currency

Crises and Monetary Policy in an Economy with Credit Constraints." European Economic Review, June 2001, 45(7), pp. 1121-50.

Ahrend, Rudiger. "Foreign Direct Investment Into RussiaPain Without Gain? A Survey of Foreign Direct Investors." Russian Economic Trends, June 2000, 9(2), pp. 26-33.

Burnside, Craig; Eichenbaum, Martin, and Rebelo, Sergio. "On The Fiscal Implications of Twin Crises." Working Paper No. 8277, National Bureau of Economic Research, May 2001.

Desai, Padma. "Why Did the Ruble Collapse in August 1998?" American Economic Review: Papers and Proceedings, May 2000, 90(2), pp. 48-52.

Economist. "Surplus to Requirements." 8 July 2000, p. 79.

Eichengreen, Barry; Rose, Andrew and Wyplosz, Charles. "Contagious Currency Crisis.” March 1997. < http://www.haas.berkeley.edu/ arose/ > .

Fischer, Stanley. "The Russian Economy at the Start of 1998.” U.S.-Russian Investment Symposium, Harvard University, Cambridge, MA, 9 January 1998.

Flemming, Marcus. "Domestic Financial Policies Under Fixed and Under Floating Exchange Rates." IMF Staff Papers, 9 November 1962.

Flood, Robert P. and Garber, Peter M. "Collapsing Exchange Rate Regimes: Some Linear Examples.” Journal of International Economics, August 1984, 17(1-2), pp 1-13.

and Jeanne, Olivier. "An Interest Rate Defense of a Fixed Exchange Rate?” Working Paper WP/00/159, International Monetary Fund, October 2000.

Kharas, Homi; Pinto, Brian and Ulatov, Sergei. "An Analysis of Russia's 1998 Meltdown: Fundamentals and Market Signals." Brookings Papers on Economic Activity, 2001, O(1), pp. 1-67. 
Krugman, Paul. "A Model of Balance-of-Payment Crises." Journal of Money, Credit, and Banking, August 1979, 11(3), pp. 311-25.

"Balance Sheets, the Transfer Problem, and Financial Crises." International Tax and Public Finance, November 1999, 6(4), pp. 459-72.

Malleret, Thierry; Orlova, Natalia and Romanov, Vladimir. "What Loaded and Triggered the Russian Crisis?" PostSoviet Affairs, April-June 1999, 15(2), pp. 107-29.

Mudell, R.A. "Capital Mobility and Stabilization Policy Under Fixed and Flexible Exchange Rates." Canadian Journal of Economics, November 1963.

Obstfeld, Maurice. "Rational and Self-Fulfilling Balance-ofPayments Crises.” American Economic Review, March 1986, 76(1), pp. $72-81$.

"The Logic of Currency Crises." Cahiers

Economiques et Monetaires, Banque de France, 1994, 43, pp. 189-213.

Popov, A. "Lessons of the Currency Crisis in Russia and in Other Countries." Problems of Economic Transition, May 2000, 43(1), pp. 45-73.

Russian Economic Trends. Various months.

Shleifer, Andre and Treisman, Daniel. Without A Map: Political Tactics and Economic Reform in Russia. Cambridge, MA: MIT Press, 2000.

Velasco, Andrés. "Financial Crises in Emerging Markets." National Bureau of Economic Research Reporter, Fall 1999, pp. 17-19. 
